\title{
Flexible Turtle Excluder Device (TED): an effective tool for Mediterranean coastal multispecies bottom trawl fisheries
}

\author{
Alessandro LUCCHETTI $^{\mathrm{a}}$, Elisa PUNZO and Massimo VIRGILI \\ National Research Council (CNR), Institute of Marine Sciences (ISMAR) of Ancona (Italy), Largo Fiera della Pesca 1, 60125 Ancona, Italy
}

Received 15 January 2016; Accepted 18 April 2016

\begin{abstract}
The effect of a flexible Turtle Excluder Device (TED) on the catching efficiency and performance of a commercial bottom trawl was tested in a gear comparison study for a Mediterranean coastal multispecies bottom trawl fishery. The device affected neither bottom trawl technical performances (horizontal and vertical net opening and door spread) nor did it increase the required towing force, hence fuel consumption remained constant. Comparison of commercial catches for the major species demonstrated that using the TED did not affect catching efficiency, while it reduced the amount of debris. The device did not influence the size of commercial species, leaving the selective performance of the trawl unmodified. Underwater video camera recordings documented that fish caught in the net swam through the grid and easily reached the cod-end, missing the TED escape opening. Easy storage and improved catch retention compared with previous devices tested in this area make the present flexible TED a practical and valuable solution to reduce turtle bycatch in coastal Mediterranean demersal multispecies fisheries.
\end{abstract}

Keywords: Loggerhead Turtle / Sea Turtle Bycatch / Trawl-Turtle Interaction / Mitigation Measures / Flexible Turtle Excluder Device (TED) / Mediterranean Sea

\section{Introduction}

Although comprising only $0.8 \%$ of the world's hydrosphere (Charbonnier et al. 1990), the Mediterranean Sea is important in terms of fisheries landings (around 360000 tonnes per year), income generated (around 1.25 billion Euros) and employment (67 843 jobs; STECF 2015; Farrugio et al. 1993; Lleonart and Maynou 2003; Papaconstantinou and Farrugio 2000) as well as being a hot-spot of biodiversity (Bianchi and Morri 2000; Myers et al. 2000; Coll et al. 2010; Eleftheriou et al. 2011; Coll and Libralato 2012). Mediterranean fisheries are multispecies, multinational and are conducted with fishing fleets of medium-large vessels, which are highly diversified, competitive and often target shared stocks (Lucchetti et al. 2014). The high fishing effort in this area, in conjunction with other anthropogenic activities, represents a significant threat to marine ecosystems, habitats and species conservation (Worm et al. 2006; Halpern et al. 2008; Tittensor et al. 2010). Bycatch has become a serious conservation challenge for some marine species such as sea turtles (Fortuna et al. 2010; Casale 2011; Casale et al. 2004, 2015; Lucchetti and Sala 2010; Lucchetti et al. 2016). Three species of sea turtles are regularly found in the Mediterranean basin (Tudela 2004): the leatherback turtle (Dermochelys coriacea), the green turtle (Chelonia mydas) and the loggerhead turtle (Caretta caretta). Loggerheads,

\footnotetext{
${ }^{a}$ Corresponding author: a.lucchetti@ismar.cnr.it
}

listed as "vulnerable" globally by the International Union for the Conservation of Nature and Natural Resources - IUCN red list (Casale and Tucker 2015), is the most abundant species in this area. Recently, its conservation has become a strategic issue in the whole Mediterranean, where commercial fishing is considered as the main driver of mortality for this species (Lucchetti and Sala 2010; Casale 2011; Wallace et al. 2011). According to recent estimates, fishing activities in the Mediterranean are responsible each year for the incidental catch of some 130000 marine turtles caught by longlines (70000 individuals), bottom trawls (40000), and fixed nets (23000), leading to more than 40000 deaths (Lucchetti and Sala 2010; Casale 2011). However, official data do not include all existing vessels and underestimate the number of small fishing boats, especially those from North African countries, suggesting an even more alarming scenario.

The loggerhead is a migratory species whose life-cycle has not been fully described for the Mediterranean (Casale et al. 2012, 2015). Therefore, in the Mediterranean Sea the introduction of management measures for the conservation of loggerhead turtles is hindered by inadequate understanding of their population dynamics and the only successful conservation effort mainly relies on the protection of eggs on nesting beaches. A rough description of the loggerhead turtle's lifecycle identifies three main habitats: (i) pelagic, involving feeding on pelagic prey in oceanic habitats (hatchlings); (ii) intermediate, when loggerheads seem to feed on pelagic as well as 
benthic prey (juveniles and subadults); and (iii) demersal, involving swimming in neritic habitats and feeding on benthic prey (adults; Tomas et al. 2001). Thus, hatchlings drift passively in ocean current systems, juveniles move from pelagic to benthic habitats, juveniles and subadults feed in coastal areas, and adults periodically migrate from demersal feeding areas to pelagic reproductive areas and back (Tomas et al. 2001).

Due to the change in habitat, the risk of fishing induced mortality varies between life stages. Mazaris et al. (2005, 2006a, 2006b) using individual based models (IBMs) for the assessment of sea turtle population viability showed how pelagic survival is crucial for population persistence. In fact, this life stage is a precursor to the neritic stage, which complex (Crouse et al. 1987) and simple (Arendt et al. 2013) matrix models have identified as the most important stage for longterm population viability. Nevertheless, Casale et al. (2015) indicated that the survival probability of the Mediterranean loggerhead is lower than that of a healthy population, especially in certain areas.

Bottom trawling chiefly impacts the demersal adults. Annual turtle bycatch in the North Adriatic, which mainly involves Italian and Croatian bottom trawlers, has been estimated as more than 6500 individuals (Lazar and Tvrtkovic 1995; Casale et al. 2004). The mortality rate related to bottom trawling is a function of towing duration (Henwood and Stuntz 1987; Sasso and Epperly 2006). If turtles caught in trawl nets are towed for a period longer than their maximum dive times, they may become comatose and drown (Lutcavage and Lutz 1997). Direct mortality due to prolonged apnoea has been estimated at around $25 \%$. However, delayed mortality due to stress, weakness, or a comatose state upon release is suspected to be high and the possibility of re-capture increases the risk of delayed mortality (Lucchetti and Sala 2010). Additional risk factors include injuries caused by contact with the bottom and debris such as rocks and timber caught in the net. Therefore, reducing the time a turtle is retained in the trawl will contribute to reducing both direct and delayed mortality.

Technical modifications directed at reducing turtle trawl bycatch began to be introduced in the 1970s through the National Marine Fisheries Service (NMFS) NOAA research program (Jenkins 2012). Among the proposed solutions, the Turtle Excluder Device (TEDs) is a grid mounted in the rear section of the trawl (extension piece) to prevent turtles and large objects from reaching the final part of the net (cod end) by directing them towards an escape opening placed on the upper or lower portion of the net (Epperly 2003). The effectiveness of this device has convincingly been documented in shrimp trawl fisheries (Crowder et al. 1994; Robins et al. 1999; Eayrs 2007; Jenkins 2012), and several countries have passed legislation making the use of TEDs compulsory (Gullett 2003; Jenkins 2012). However, their effectiveness in multispecies fisheries is currently debated. Some researchers (Laurent and Lescure 1994; Laurent et al. 1996; Casale et al. 2004) have recently concluded that current TEDs are unsuitable for Mediterranean multispecies bottom trawl fisheries, because even though they effectively exclude turtles, they might also exclude large commercial species. Sala et al. (2011) recently designed and tested a stiff aluminium TED. This device effectively excluded turtles and large marine litter from the trawl, but exhibited some major weaknesses related to its problematic handling (entanglement with the net and stern components during shooting and hauling, damage to the net, the device itself, or both, problems with safe winding of net around a standard winch, time wasting).

The present study was initiated to test a new prototype of a TED designed to address these problems. The effect of a flexible Turtle Excluder Device (TED) on the catching efficiency and performance of a commercial bottom trawl was tested in a gear comparison study in a Mediterranean coastal multispecies bottom trawl fishery. The objectives of the study were: (i) to compare the catch rates of commercial species, discarded species, and debris (anthropogenic litter and natural debris such as timber, rocks, and shells); (ii) to document any size selection effect induced by the TED using length-based analysis of the main commercial species; (iii) to document grid functioning, fish behaviour around the grid, and any loss of target species by filming the trawl with an underwater video camera, and (iv) to assess whether the TED influenced technical net performance.

\section{Materials and methods}

\subsection{Study area and sea trials}

This study was conducted in neritic $(<100 \mathrm{~m})$ waters of the northern Adriatic Sea (Fig. 1) which provides a foraging habitat for loggerhead sea turtles (Camiñas 2004; Casale et al. 2004; Lucchetti and Sala 2010). Data regarding stranded, caught or rescued individuals in the Adriatic (Fig. 1; Adriatic Sea Turtle Database, 2015) confirm a high abundance of turtles in the area.

Sea trials were conducted aboard the Italian Research Vessel "G. Dallaporta" (810 kW of engine power, $35.30 \mathrm{~m}$ length overall, and 285 GT of tonnage). Fifty-five bottom trawl trials were performed in three different periods in 2014 (24 in winter, 16 in spring and 15 in autumn) on a sandy-muddy bottom at a depth between 20 and $40 \mathrm{~m}$ (average $33 \mathrm{~m}$; Table 1) in a fishing ground usually exploited by commercial vessels. Tow duration and towing speed were one hour and 3-4 knots on average, respectively.

Since the fish population in this area is not expected to vary considerably between hauls during the same period, the two nets (with and without TED) were tested successively over a limited time period (Sala et al. 2008). The net fitted with the TED was the experimental gear and the traditional net was used as a "control".

\subsection{Trawl gear and TED specifications}

For all hauls the same gear rigging and net were used. For TED trials, the TED was inserted in the rear part (extension piece). The gear was a typical Italian commercial trawl commonly used in the central Adriatic made entirely of knotless polyamide (PA) netting, around $58 \mathrm{~m}$ long from wing tips to codend, with 600 meshes in the top panel at the level of the footrope, and a $60.3 \mathrm{~m}$ footrope comprising a $36 \mathrm{~mm}$ combined rope weighted with $73.2 \mathrm{~kg}$ of sinkers over its whole 


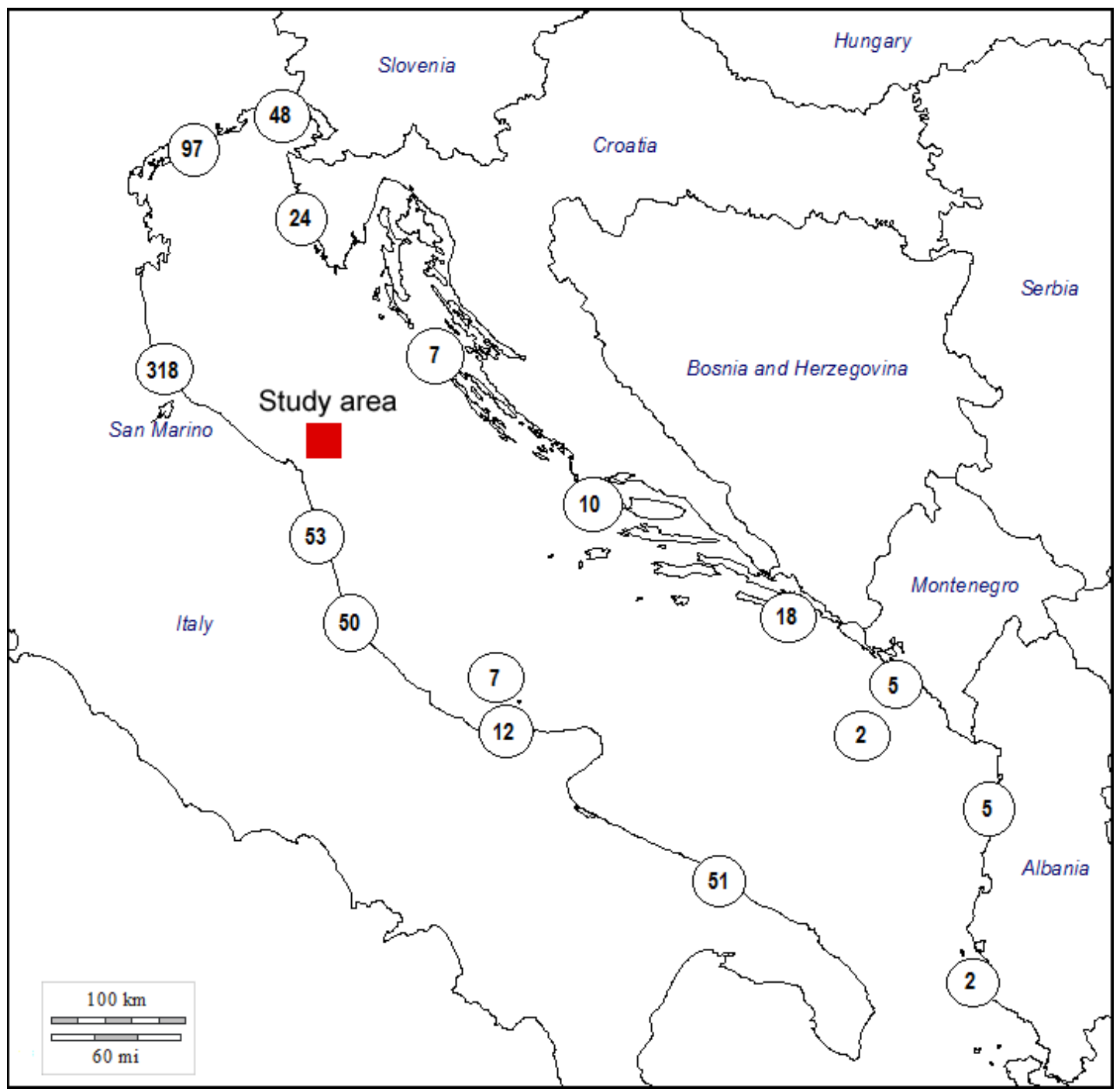

Fig. 1. Location of study area (A) and number of Caretta caretta stranded, caught or rescued in the Adriatic Sea in 2013 (in circles). Adriatic Sea Turtles Database (2015).

Table 1. Standardized catch $(\mathrm{kg} / \mathrm{h})$ and gear performance measures by season. TED: net equipped with a TED; TRADIT: net in a traditional configuration (without TED). Catch is separated into categories: COM: commercial; DIS: discards; DEB: debris; TOT: total. HNO: Horizontal Net Opening; VNO: Vertical Net Opening; DS: Door Spread; TF: Towing Force. s.e.: standard error.

\begin{tabular}{|c|c|c|c|c|c|c|c|c|c|c|c|c|}
\hline Trawl & Season & $\begin{array}{c}\text { N. } \\
\text { hauls }\end{array}$ & & $\begin{array}{c}\text { Depth } \\
{[\mathrm{m}]}\end{array}$ & $\begin{array}{c}\mathrm{HNO} \\
{[\mathrm{m}]}\end{array}$ & $\begin{array}{c}\mathrm{VNO} \\
{[\mathrm{m}]} \\
\end{array}$ & $\begin{array}{c}\mathrm{DS} \\
{[\mathrm{kgf}]}\end{array}$ & $\begin{array}{c}\mathrm{TF} \\
{[\mathrm{kg} / \mathrm{h}]}\end{array}$ & $\begin{array}{l}\mathrm{COM} \\
{[\mathrm{kg} / \mathrm{h}]}\end{array}$ & $\begin{array}{c}\text { DIS } \\
{[\mathrm{kg} / \mathrm{h}]}\end{array}$ & $\begin{array}{c}\text { DEB } \\
{[\mathrm{kg} / \mathrm{h}]}\end{array}$ & TOT \\
\hline \multirow{6}{*}{ TED } & \multirow{2}{*}{ Winter } & \multirow{2}{*}{5} & Mean & 33.2 & 14.7 & 1.1 & 56.5 & 3169 & 8.2 & 12.6 & 2.5 & 23.2 \\
\hline & & & s.e. & 4.9 & 0.3 & 0.0 & 2.0 & 86.2 & 1.7 & 1.8 & 0.7 & 2.5 \\
\hline & \multirow{2}{*}{ Spring } & \multirow{2}{*}{12} & Mean & 33.5 & 14.9 & 1.2 & 58.7 & 3104.9 & 41.8 & 25.0 & 9.2 & 76.0 \\
\hline & & & s.e. & 4.3 & 0.6 & 0.0 & 2.8 & 111.3 & 5.3 & 5.0 & 5.9 & 10.1 \\
\hline & \multirow{2}{*}{ Autumn } & \multirow[b]{2}{*}{8} & Mean & 33.0 & 16.5 & 1.0 & 60.4 & 2955.5 & 26.2 & 8.2 & 4.7 & 39.1 \\
\hline & & & s.e. & 0.9 & 0.6 & 0.1 & 2.5 & 97.5 & 2.1 & 1.4 & 0.4 & 2.6 \\
\hline \multirow{6}{*}{ TRADIT } & \multirow{2}{*}{ Winter } & \multirow{2}{*}{19} & Mean & 31.0 & 14.6 & 1.2 & 55.1 & 2979.5 & 10.4 & 11.7 & 18.1 & 40.2 \\
\hline & & & s.e. & 4.5 & 0.9 & 0.1 & 4.1 & 159.8 & 0.9 & 5.2 & 6.4 & 12.0 \\
\hline & \multirow[b]{2}{*}{ Spring } & \multirow[b]{2}{*}{4} & Mean & 39.8 & 15.1 & 1.2 & 63.7 & 3259.0 & 21.4 & 29.9 & 8.5 & 59.8 \\
\hline & & & s.e. & 0.9 & 0.2 & 0.0 & 0.5 & 42.3 & 2.4 & 2.9 & 0.3 & 4.2 \\
\hline & \multirow{2}{*}{ Autumn } & \multirow[b]{2}{*}{7} & Mean & 35.1 & 16.2 & 1.1 & 56.1 & 2949.0 & 34.3 & 9.8 & 6.2 & 50.3 \\
\hline & & & s.e. & 2.1 & 0.3 & 0.0 & 1.3 & 76.5 & 4.3 & 2.0 & 1.1 & 5.5 \\
\hline
\end{tabular}




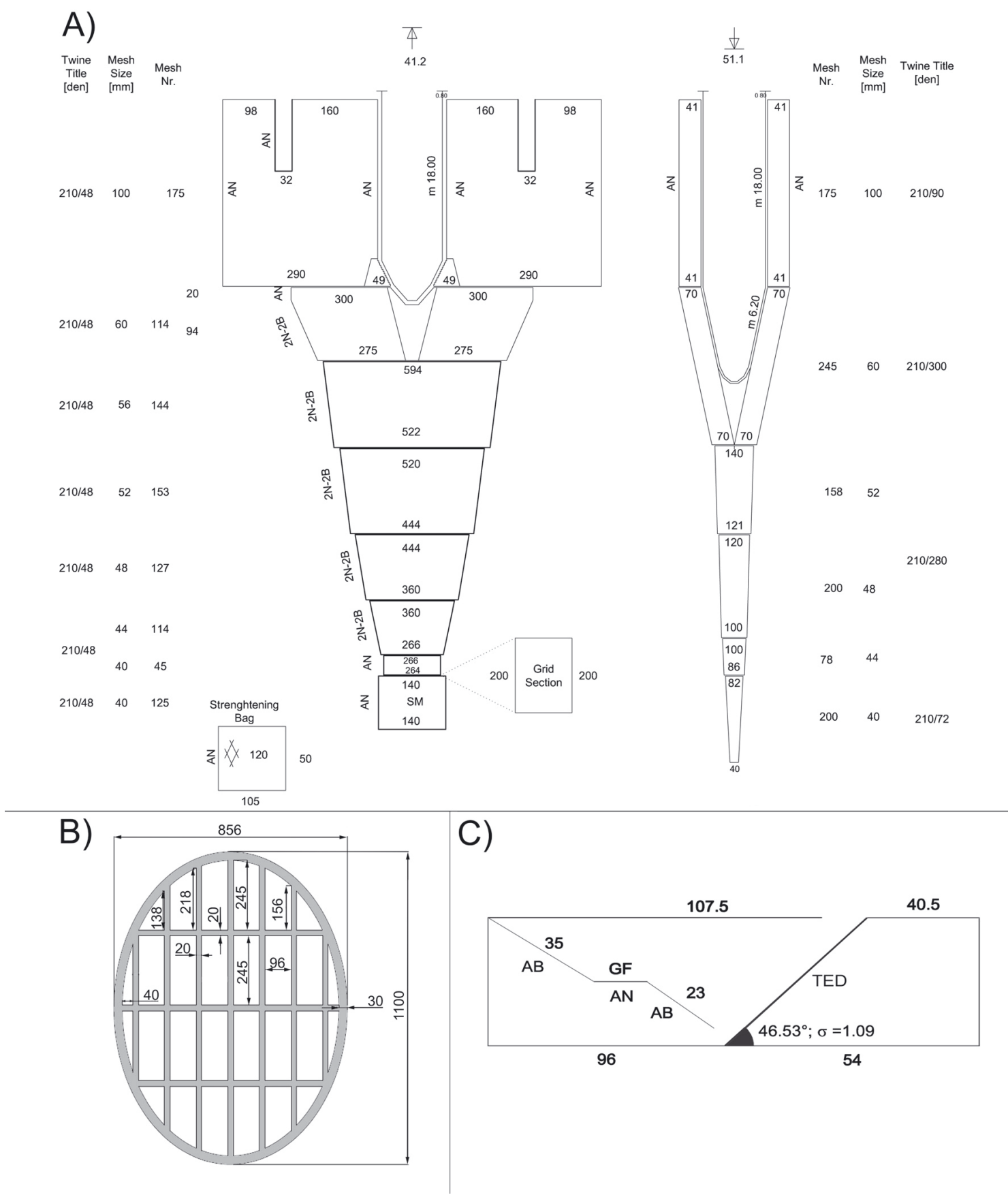

Fig. 2. (A) Design and gear rigging of the trawl used in the study and details of TED positioning. SM. Square Mesh; (B) Design of the flexible TED used in the study. Details and size (in mm); (C) Technical drawing of TED rigging (lateral view). GF, Guiding Funnel. AB and AN, types of net cuttings (figures indicate number of meshes). The average grid angle recorded during sampling is also reported.

length (Fig. 2A). A $40 \mathrm{~mm}$ square mesh codend complying with European Council Regulation 1967/2006 was used in all hauls. Rigging components were those of typical central Adriatic trawl fisheries.

The flexible TED (FLEXGRID; Fig. 2B) was made of an alloy of high strength plastic material. Its characteristics allow it both to maintain a stiff configuration during trawling and to ride on the net drum as the net was recovered. The flexible TED was designed according to the technical specifica- tions suggested by Mitchell et al. (1995): height: $1130 \mathrm{~mm}$; width: $845 \mathrm{~mm}$; circumference: $3110 \mathrm{~mm}$; bar diameter: $20 \mathrm{~mm}$; spacing between bars: $96 \mathrm{~mm}$. The grid was mounted on a tubular netting section (Fig. 2C) to facilitate insertion and removal and placed immediately in front of the codend. The escape opening was cut on the upper portion of the net just before the TED; it was covered by a netting panel that had three sides sewn to the net, to prevent loss of commercial species (e.g. hake, mackerel, red mullet, shrimp), and a 
free side. This panel functioned as an escape hatch for larger and heavier objects, allowing any turtles that entered the net to swim up and out. An accelerator funnel installed before the TED, as recommended by Mitchell et al. (1995), drove the fish down and away from the exit panel and through the TED bars, towards the codend.

Some previous studies testing TEDs in Mediterranean bottom trawling (Bahamon et al. 2007; Sala et al. 2011) attached a netting bag to the escape opening, to capture any fish and material that were deflected by the TED away from the codend, thus obtaining a precise estimate of its action and more accurate catch comparison. In the present study such a method was felt to be unsuitable, because it might have influenced TED behaviour during towing and altered fish escape rates.

\subsection{Monitoring gear parameters}

Trawl performance (horizontal and vertical net opening [HNO and VNO, respectively] and door spread [DS]) with and without the TED were measured using the SIMRAD PI50 system (Norway) to assess the grid's effects on net behaviour. Towing force $[\mathrm{TF}]$ was measured with 2 TEKKAL electronic load cells (Germany) to assess the influence of the TED on net drag and fuel consumption. All instruments were linked via RS232/485 serial ports to a laptop, which automatically controlled data acquisition and monitored system function in real-time via an in-house developed software programme. Data were recorded on the hard disk every $10 \mathrm{~s}$. A dataset was recorded for each haul and processed in the office (Prat et al. 2008; Sala and Lucchetti 2011).

A one-way analysis of variance (ANOVA) was applied to mean gear performance parameters per haul for the two types of nets (with and without TED) to assess any potential effects of TED on trawl behaviour.

The TED angle is a key factor influencing TED efficiency and preventing loss of commercial species during the tow (Mitchell et al. 1995; Eayrs 2007). An angle less than $40^{\circ}$ may involve shrimp loss due to water diversion through the exit hole. Angles greater than $55^{\circ}$ can prevent turtle escape and deflection of trash, clogging the grid. The correct TED angle was continuously monitored by an angle sensor (Star-Oddi DST pitch \& roll, Iceland) that collected pitch and roll angle data every $10 \mathrm{~s}$.

\subsection{Catch analysis}

Catches were sorted into commercial, discard and debris fractions. Rocks, timber, marine litter and trash were considered debris. Commercial and discard species were classified to the lowest possible taxonomic level, and their weight was standardised per hour $(\mathrm{g} / \mathrm{h})$. For the main commercial species length, i.e. total length (TL) for fishes, mantle length (ML) for cephalopods and carapace length (CL) for crustaceans, was measured to the lower $0.5 \mathrm{~cm}$; random subsamples were taken in case of abundant catches. For sea turtles carapace length and width (straight and curved), body weight and sex (if possible) were collected. Successively, turtles were rescued as established by Italian Ministry of Environment guidelines. Tow duration was taken as the time between optimal gear opening and the time when speed was reduced to recover the warp.

Catch rates were transformed as $\log (x+1)$ to normalise values (Cochran 1977). Firstly, a two-way analysis of variance (ANOVA) was applied to the standardised catch within each category (commercial, discard and debris) to assess the effect of factors "Net" and "Season". Prior to statistical analysis, normal distribution and homoscedasticity of variances were evaluated through Kolmogorov-Smirnov and Bartlett tests, respectively (Lindman 1992). The Tukey HSD test (Lindman 1992) was then performed to make comparisons across all pairs of group means (seasons) when corresponding ANOVA tests had $p$-values $<0.05$.

Differences between standardised catches of commercial species for the two net types and three seasons (main effects and interactions) were assessed using permutation analysis of variance (PERMANOVA; 999 permutations of raw data; Anderson 2001; McArdle \& Anderson 2001). The test was based on the Bray-Curtis dissimilarity matrix calculated on log-transformed data. In case of significant interactions between the factors "Net" and "Season", pair-wise tests were applied. Moreover, multivariate multiple permutation tests (SIMPER, Similarity Percentages, PRIMER; Clarke 1993) were used to determine which species were responsible for differences between net types.

The length frequency distributions of the main commercial species caught in each season with and without the TED were pooled and compared by two-sample Kolmogorov-Smirnov tests (Sokal and Rohlf 1995), to investigate possible TED effects on the sizes of fishes caught.

\subsection{Underwater evaluation of TED performance}

TED performance was monitored using an underwater camera (UWTV; GoPro Hero3, US) covered with an additional suit to prevent damage during towing operations. Due to high water turbidity, the camera was mounted $0.5 \mathrm{~m}$ from the TED. The fisheye consistently provided a full view of the TED.

The UWTV was used to monitor grid position during hauling, exclusion by the grid of commercial catches, fish reaction to the TED and fish behaviour inside the net, and grid effectiveness in preventing debris from entering the cod-end. Images were recorded directly by the camera and downloaded at the end of each haul.

\section{Results}

\subsection{Gear performance}

The flexible TED did not affect routine on-board procedures or the time required for shooting $(10 \pm 1 \mathrm{~min}$ in both cases) or hauling the net (15 $\pm 2 \mathrm{~min}$ in both cases). The mean TED angle recorded during towing operations was $46.53^{\circ} \pm 1.09$ (Fig. 2C).

The TED did not seem to affect bottom trawl behaviour since technical parameters did not show any significant differences between hauls with and without the device (Tables 1 
Table 2. Summary of one-way ANOVA applied to mean values of gear performance per haul to assess the difference between two types of nets (with and without TED). Note that some parameters were missing for certain hauls.

\begin{tabular}{ccccccc}
\hline \multirow{2}{*}{ Variable } & $\begin{array}{c}\text { Variance } \\
\text { component }\end{array}$ & $\begin{array}{c}\text { Sum of } \\
\text { Squares }\end{array}$ & $d f$ & $\begin{array}{c}\text { Mean } \\
\text { Square }\end{array}$ & \multirow{2}{*}{$F$} & $p$-value \\
\hline \multirow{2}{*}{ Horizontal Net Opening } & Between net type & 1.65 & 1 & 1.65 & \multirow{2}{*}{0.641} & \multirow{2}{*}{0.427} \\
& Within net type & 133.92 & 52 & 2.58 & & \\
Vertical net Opening & Between net type & 0.05 & 1 & 0.05 & \multirow{2}{*}{2.583} & 0.114 \\
& Within net type & 1.06 & 52 & 0.02 & & \\
\multirow{2}{*}{ Door Spread } & Between net type & 61.40 & 1 & 61.40 & \multirow{2}{*}{1.195} & 0.280 \\
& Within net type & 2516.89 & 49 & 51.37 & & \\
Towing Force & Between net type & 49506.33 & 1 & 49506.33 & \multirow{2}{*}{0.637} & 0.429 \\
& Within net type & 4122198.51 & 53 & 77777.33 & & \\
\hline
\end{tabular}

Table 3. Summary of Two-way ANOVA for each catch category to assess the effect of the factors "Net" (with and without TED) and "Season" (Winter, Spring, Autumn). TED: net equipped with a TED; TRADIT: net in a traditional configuration (without TED).

\begin{tabular}{ccccccc}
\hline Variable & $\begin{array}{c}\text { Sum of } \\
\text { Squares }\end{array}$ & $d f$ & $\begin{array}{c}\text { Mean } \\
\text { Square }\end{array}$ & $F$ & $p$-value & $\begin{array}{c}\text { Tukey } \\
\text { test }\end{array}$ \\
\hline COMMERCIAL & & & & & & \\
Net & 0.004 & 1 & 0.004 & 0.072 & 0.790 & \\
Season & 1.985 & 2 & 0.992 & 17.897 & $<0.001$ & $\mathrm{~W} \neq \mathrm{A} ; \mathrm{S} \neq \mathrm{A}$ \\
Net $\times$ Season & 0.301 & 2 & 0.150 & 2.712 & 0.076 & \\
Residuals & 2.717 & 49 & 0.055 & & & \\
\hline DISCARDS & & & & & & \\
$\quad$ Net & 0.008 & 1 & 0.008 & 0.064 & 0.801 & \\
Season & 1.938 & 2 & 0.969 & 8.081 & 0.001 & $\mathrm{~S} \neq \mathrm{W} ; \mathrm{S} \neq \mathrm{A}$ \\
Net $\times$ Season & 0.301 & 2 & 0.150 & 1.253 & 0.295 & \\
Residuals & 5.877 & 49 & 0.120 & & & \\
\hline DEBRIS & & & & & & \\
$\quad$ Net & 2.022 & 1 & 2.022 & 15.335 & $<0.001$ & \\
Season & 0.011 & 2 & 0.006 & 0.042 & 0.959 & \\
Net $\times$ Season & 1.050 & 2 & 0.525 & 3.981 & 0.025 & \\
Residuals & 6.460 & 49 & 0.132 & & & \\
\hline
\end{tabular}

and 2). The mean values of the geometric parameters monitored with the acoustic sensors showed that horizontal net opening (HNO) ranged from 14.6 to $16.2 \mathrm{~m}$ without TED and from 14.7 to $16.5 \mathrm{~m}$ with TED ( $p$-value: 0.427 ; Table 1 ), the range recorded for door spread (DS) was 55.1-63.7 $\mathrm{m}$ without TED and 56.5-60.4 m with TED ( $p$-value 0.280; Table 2), vertical net opening (VNO) was 1.1-1.2 $\mathrm{m}$ in all hauls in both configurations (Table 1). Similarly, the towing force (TF) did not show any significant differences between the two nets, ranging from 2949 to $3259 \mathrm{kgf}$ without TED and from 2955 to $3169 \mathrm{kgf}$ with TED ( $p$-value: 0.429; Table 1). Thus, the area swept during trawling as well as the fuel consumption (directly linked with the towing force) were not affected by the presence of the TED. Finally, neither damage nor fractures were ever detected in the trawl or the TED after net recovery.

\subsection{Catch analysis}

Data were collected from 55 hauls, 25 with and 30 without the TED. The mean standardised commercial catches, discards, and debris obtained with each configuration in the three seasons investigated are shown in Table 1. On average, commercial catches accounted for $52 \%$ of total weight for hauls with the TED and for $43 \%$ without TED, whereas the discard fractions were similar (36\% with and $32 \%$ without TED). The TED reduced debris from $24 \%$ to $11 \%$ on average.

The two-way ANOVA applied to the standardised catch of each category showed significant differences among nets only for debris, which decreased using TED (Table 3). Significant differences were found for all categories among seasons, except for debris, with winter having the lowest mean catches (Fig. 3; Table 3). These results confirm the high seasonality of Mediterranean demersal fisheries (Tudela 2004).

The mean catch of the commercial species caught in each season did not show any clear differences (Fig. 3). The twoway PERMANOVA confirmed this result (Table 4) because no statistical differences were observed for the factor "Net" and for the interaction "Net-Season". PERMANOVA also evidenced significant differences in the mean commercial catches among Seasons. Pair-wise tests showed highly significant differences among all season combinations (Table 4). SIMPER analysis revealed that Trachurus mediterraneus, Scomber japonicus and Illex coindetii were mainly responsible for the dissimilarity between total commercial catches in winter and spring, while Mullus barbatus, Chelidonichthys lucernus and Loligo vulgaris explained the dissimilarity between winter and autumn (Table 5).

The size frequency distributions of the major commercial species caught by the two nets (Fig. 4) showed a significant 

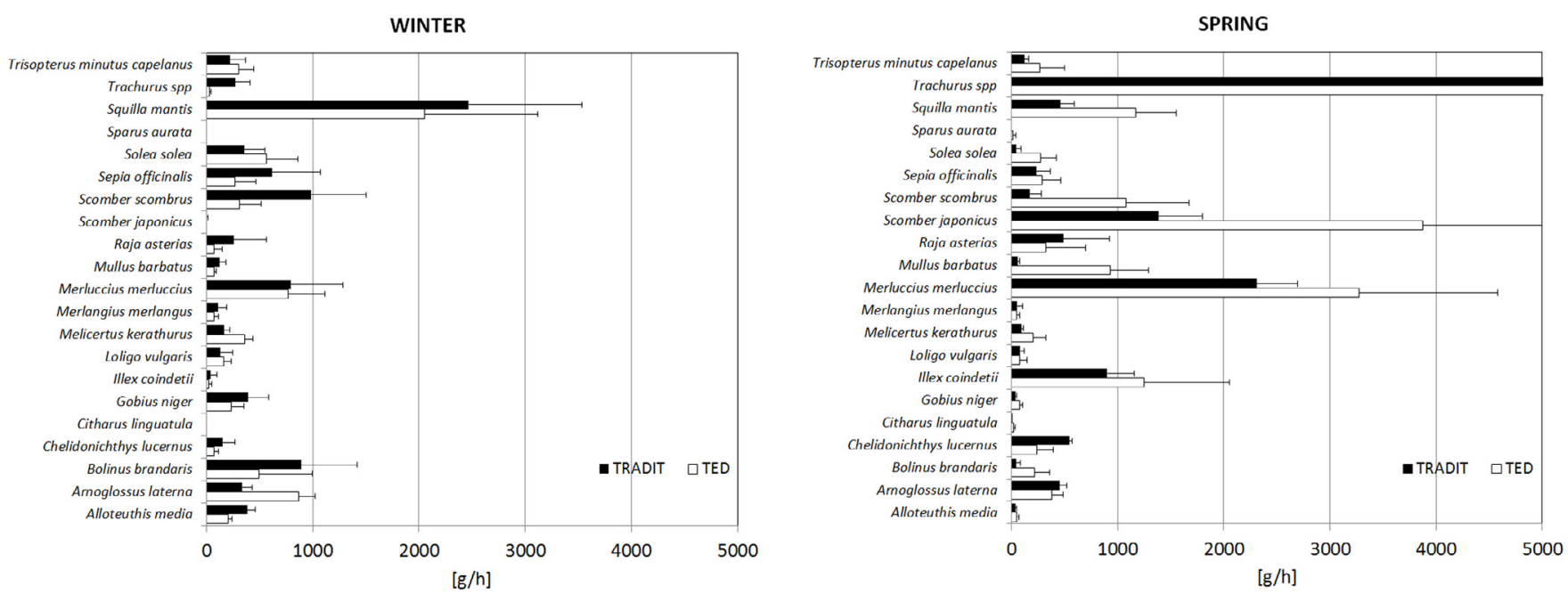

AUTUMN
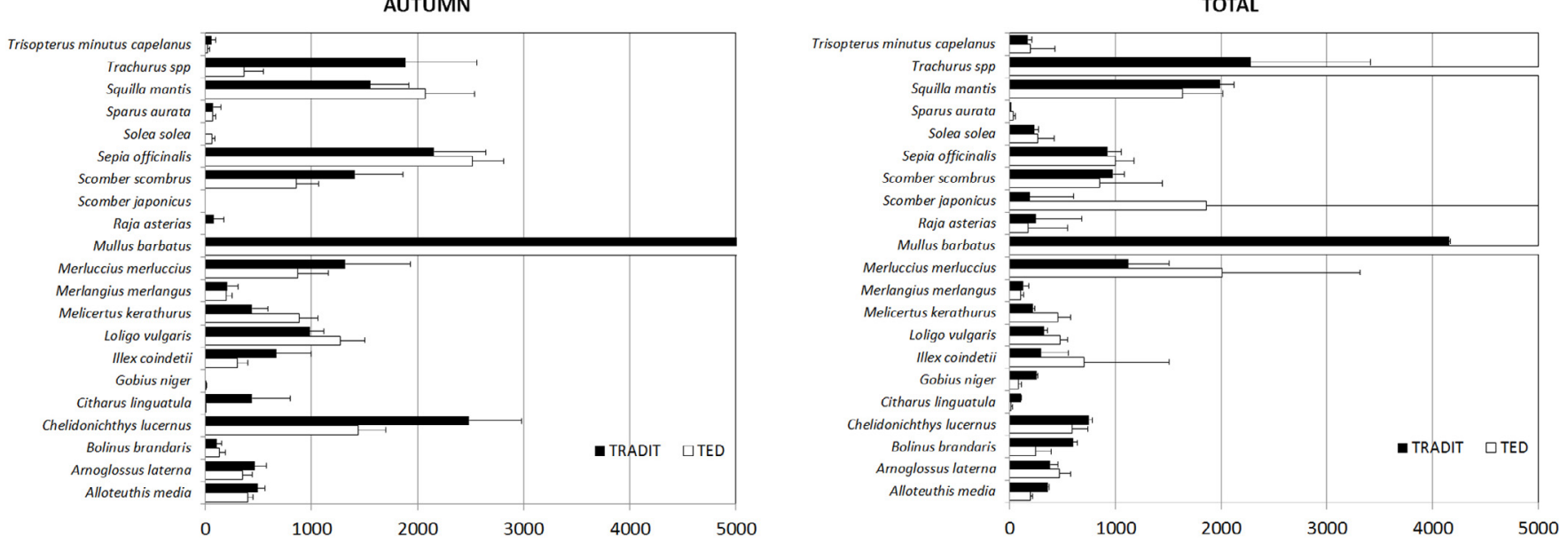

Fig. 3. Mean catch and standard errors $[\mathrm{g} / \mathrm{h}]$ of the major species caught by the trawl with and without the TED in the three seasons investigated and in total.

Table 4. Summary of Two-way PERMANOVA analysis applied to log transformed biomass data of Commercial category, considering factors "Net" (with and without TED) and "Season" (Winter, Spring, Autumn).

\begin{tabular}{ccccccc}
\hline 2-way PERMANOVA & & & & & \\
Factor & $d f$ & SS & MS & Pseudo-F & $p$-value & $\begin{array}{c}\text { Unique } \\
\text { permutations }\end{array}$ \\
\hline Net & 1 & 810.07 & 810.07 & 1.1458 & 0.324 & 997 \\
Season & 2 & 14450 & 7225.2 & 10.22 & 0.001 & 996 \\
Net $\times$ Season & 2 & 1994.6 & 997.28 & 1.4106 & 0.14 & 998 \\
Residuals & 49 & 34643 & 707 & & & \\
Total & 54 & 55404 & & & \\
\hline PAIR-WISE TESTS between seasons & & & \\
Pair & $t$ & $p$-value & & \\
W-S & 2.6173 & 0.001 & & & \\
W-A & 3.4067 & 0.001 & & 999 & \\
S-A & 3.9666 & 0.001 & & \\
\hline
\end{tabular}


Table 5. Summary of SIMPER analysis comparing commercial species catch composition between seasons. Average abundance by net type $\left(\mathrm{kg} \mathrm{h}^{-1}\right), \%$ contribution and \% cumulative contribution to the average dissimilarity are given for commercial species that were important for seasonal differences. TED: net equipped with a TED; TRADIT: net in a traditional configuration (without TED).

\begin{tabular}{|c|c|c|c|c|c|c|}
\hline \multirow{2}{*}{ Species } & \multicolumn{2}{|c|}{ Average Abundance } & \multirow{2}{*}{ Average dissimilarity } & \multirow{2}{*}{ Disssimilarity/SD } & \multirow{2}{*}{$\%$ Contribution } & \multirow{2}{*}{$\begin{array}{c}\% \text { Cum. } \\
\text { contribution }\end{array}$} \\
\hline & TRADIT & TED & & & & \\
\hline \multicolumn{7}{|c|}{ Winter-Spring: Average dissimilarity $=49.97$} \\
\hline $\begin{array}{c}\text { Trachurus } \\
\text { mediterraneus }\end{array}$ & 3.22 & 9.8 & 3.45 & 2.28 & 6.9 & 6.9 \\
\hline Scomber japonicus & 0.34 & 6.9 & 3.36 & 2.61 & 6.73 & 13.63 \\
\hline Illex coindetii & 0.77 & 5.49 & 2.52 & 1.74 & 5.04 & 18.67 \\
\hline Bolinus brandaris & 3.1 & 2.23 & 1.82 & 1.03 & 3.64 & 22.31 \\
\hline Scomber scombrus & 4.48 & 4.87 & 1.77 & 1.09 & 3.54 & 25.85 \\
\hline Eutrigla gurnardus & 3.1 & 4.29 & 1.74 & 1.23 & 3.48 & 29.32 \\
\hline $\begin{array}{c}\text { Chelidonichthys } \\
\text { lucernus }\end{array}$ & 2.1 & 3.53 & 1.68 & 1.1 & 3.36 & 32.68 \\
\hline Diplodus annularis & 0.27 & 3.13 & 1.65 & 1 & 3.31 & 35.99 \\
\hline Sepia officinalis & 3.75 & 3.86 & 1.63 & 1.29 & 3.27 & 39.26 \\
\hline Alloteuthis media & 5.74 & 2.71 & 1.63 & 1.37 & 3.26 & 42.53 \\
\hline $\begin{array}{l}\text { Merluccius } \\
\text { merluccius }\end{array}$ & 4.9 & 7.59 & 1.6 & 1.06 & 3.2 & 45.73 \\
\hline $\begin{array}{l}\text { Trisopterus min. } \\
\text { capelanus }\end{array}$ & 3.01 & 2.68 & 1.6 & 1.15 & 3.2 & 48.93 \\
\hline Solea solea & 4.23 & 3.49 & 1.58 & 1.11 & 3.15 & 52.09 \\
\hline \multicolumn{7}{|c|}{ Winter-Autumn: Average dissimilarity $=46.65$} \\
\hline Mullus barbatus & 3.72 & 9.37 & 3 & 2.51 & 6.46 & 6.46 \\
\hline Chelidonichthys lucernus & 2.1 & 7.4 & 2.86 & 1.79 & 6.15 & 12.62 \\
\hline Loligo vulgaris & 1.97 & 6.94 & 2.69 & 1.7 & 5.79 & 18.41 \\
\hline Illex coindetii & 0.77 & 5.71 & 2.67 & 2.68 & 5.76 & 24.17 \\
\hline Gobius niger & 5.2 & 0.24 & 2.63 & 2.82 & 5.66 & 29.82 \\
\hline Sepia officinalis & 3.75 & 7.69 & 2.15 & 1.31 & 4.64 & 34.46 \\
\hline Solea solea & 4.23 & 1.28 & 1.97 & 1.34 & 4.25 & 38.71 \\
\hline Bolinus brandaris & 3.1 & 3.81 & 1.97 & 1.77 & 4.24 & 42.95 \\
\hline Trachurus mediterraneus & 3.22 & 5.99 & 1.78 & 1.32 & 3.84 & 46.79 \\
\hline Scomber scombrus & 4.48 & 6.42 & 1.67 & 1.01 & 3.6 & 50.4 \\
\hline
\end{tabular}

Table 6. Summary of Kolmogorov-Smirnov test (K-S test) applied to the size frequency distributions of the main commercial species caught with and without TED. Mean length ( \pm standard error) is also reported.

\begin{tabular}{cccrrr}
\hline & \multicolumn{2}{c}{ N. Measured } & \multicolumn{2}{c}{ Mean length [cm] } & $p$-value \\
\cline { 2 - 4 } & \multicolumn{1}{c}{ TED } & \multicolumn{1}{c}{ No-TED } & \multicolumn{1}{c}{ TED } & \multicolumn{1}{c}{ No-TED } & (K-S test) \\
\hline Melicerthus kerathurus & 306 & 263 & $3.7 \pm 0.0$ & $3.6 \pm 0.0$ & 0.276 \\
Merluccius merluccius & 812 & 612 & $18.9 \pm 0.2$ & $18.7 \pm 0.2$ & 1.300 \\
Mullus barbatus & 3797 & 4195 & $14.4 \pm 1.5$ & $13.8 \pm 1.8$ & 0.107 \\
Sepia officinalis & 306 & 263 & $7.5 \pm 0.1$ & $8.2 \pm 0.2$ & 0.865 \\
Solea solea & 93 & 127 & $21.1 \pm 0.3$ & $19.6 \pm 0.1$ & 0.017 \\
Trachurus mediterraneus & 3868 & 1341 & $21.4 \pm 0.1$ & $17.5 \pm 0.1$ & $<0.001$ \\
\hline
\end{tabular}

difference (Kolmogorov-Smirnov test) only for $T$. mediterraneaus and Solea solea, while the modal class was similar for all species (Table 6). The trawl fitted with the TED generally caught commercial species with a greater mean length except for S. officinalis. The catch of M. merluccius and S. solea specimens below the Minimum Conservation Reference Size (MCRS, as established by EC Reg. 1967/2006) were common in both nets.

The UWTV showed that two turtles were released from the net with TED, while one turtle was caught in the cod-end of the net without TED. However, the low number of encountered turtles prevented any statistical evaluation of the TED efficacy for turtles. Nonetheless, the UWTV recordings of large objects (such as a log) ejected from the TED opening suggest that a turtle, blocked by the grid, would have been able to escape through the opening. The recordings also demonstrated that fish retained in the net were able to move freely in the net but completely ignored the escape window. In particular, fish swam upstream (towards the mouth of the net) during towing, whereas at the end of the haul, when vessel speed was reduced, they turned around, swam through the TED bars, and reached the cod-end, missing the escape opening. Also large flatfish, such as Scophthalmus rhombus and Raja asterias, behaved in this way and reached the cod-end. 

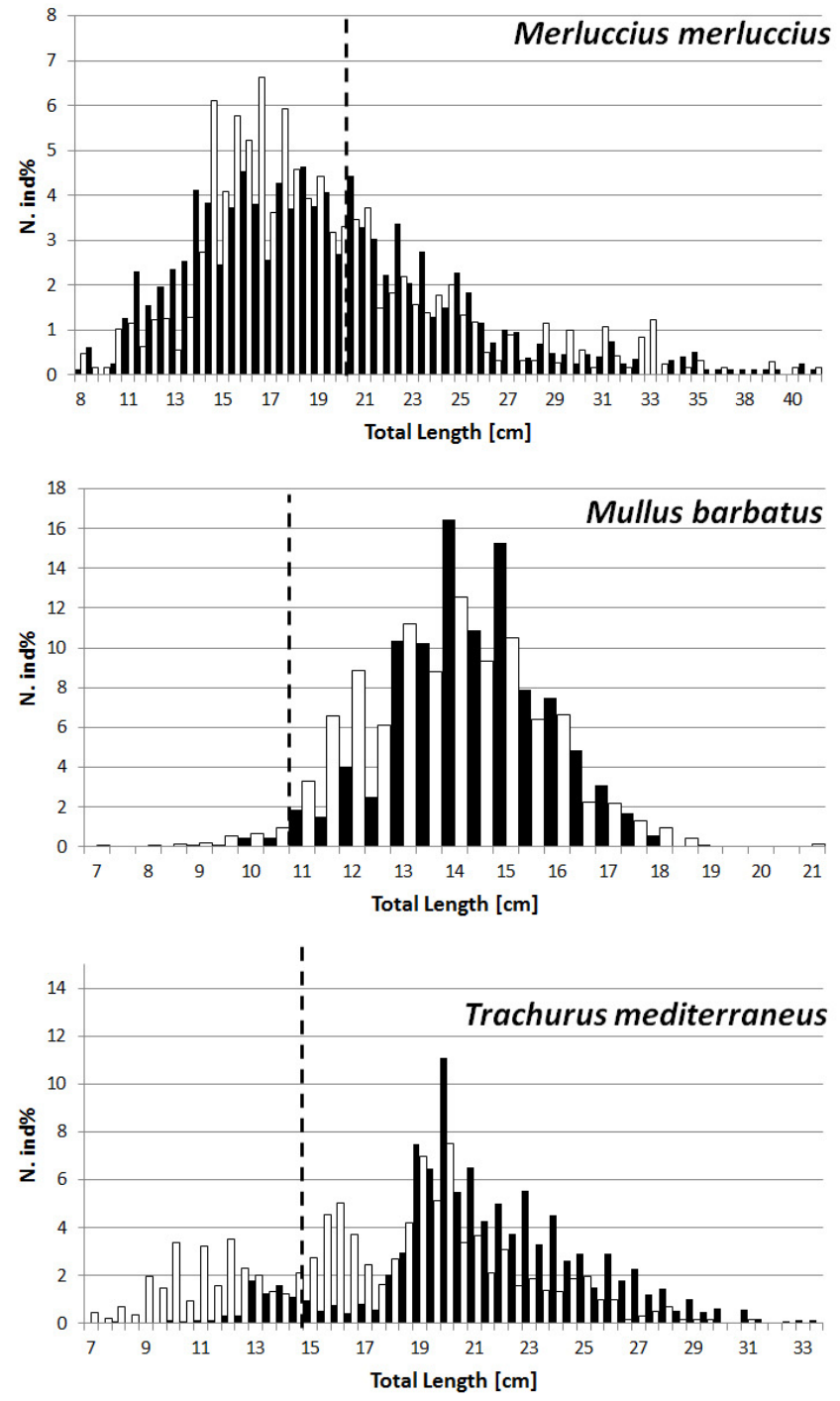
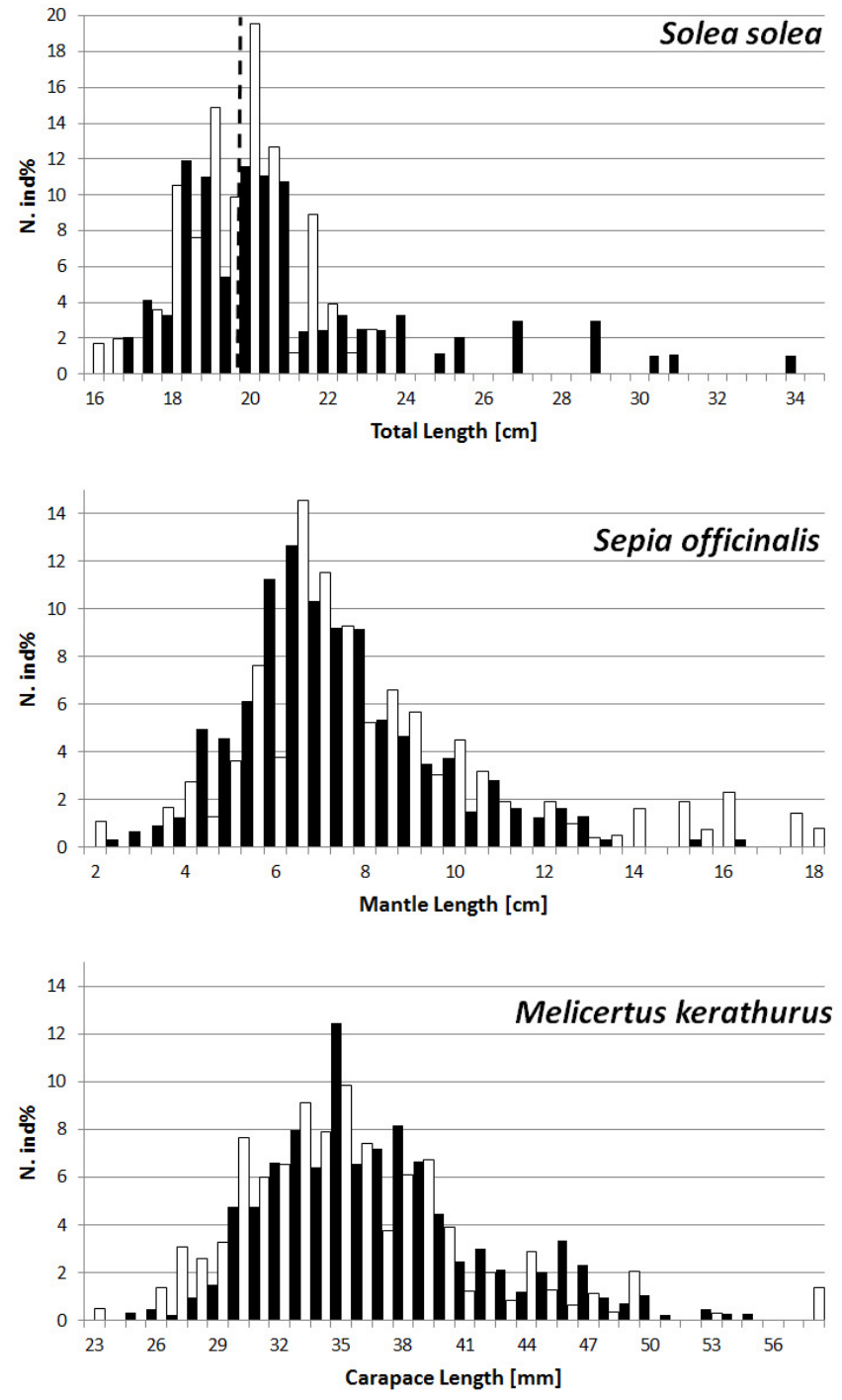

TED

TRADITIONAL

Fig. 4. Size frequency distributions of the major commercial species. Total length (fish), mantle length (cephalopods) and carapace length (crustaceans) are reported. Dotted lines indicate the Minimum Conservation Reference Size (MCRS).

Finally, the UWTV images also documented that a large amount of marine litter was stopped by the grid, thus enhancing the quality of fish caught in the cod-end.

\section{Discussion}

This is the first study comparing the technical performance and catching efficiency of a typical bottom trawl and those of the same net fitted with a flexible TED in the Mediterranean Sea.

Previous tests with TEDs in this area used stiff grids (Lazar and Tvrtkovic 1995; Sala et al. 2011), which considerably affected both bottom trawl behaviour and on-board operations, especially because its stiffness involved a high risk of damage to the TED and to the net during hauling (Sala et al. 2011). Flexible size sorting grids have been tested in previous studies (Sardà et al. 2006; Bahamon et al. 2007) with a different aim, as technical measures to enhance bottom trawl selectivity and reduce the catch of juveniles (in fact the space between the bars was $20 \mathrm{~mm}$ vs. $96 \mathrm{~mm}$ in the present case). A narrow space between the bars is a practical solution to reduce bycatch in shrimp or Norway lobster fisheries (He and Balzano 2012), but in multispecies fisheries it entails a high risk of losing commercial species.

The present TED was sufficiently stiff to maintain a rigid configuration during towing, and sufficiently flexible for safe winding around a standard net winch. Therefore, it did not require changes to on-board procedures and did not induce a loss of time for fishermen during hauling. Some authors (e.g., Mitchell et al. 1995) have suggested that TEDs should be installed at an angle of $30^{\circ}-55^{\circ}$ from the horizontal to ensure turtle exclusion and shrimp retention. The TED rigging tested in this study provided an optimum angle $\left(46^{\circ}\right)$, suggesting that this configuration can be applied efficiently in other multispecies trawl fisheries in the Mediterranean. 
The challenges posed to fisheries management by the introduction of a new technology, such as the TED, include the need to balance precautionary goals (e.g. reducing turtle mortality) and economic objectives (e.g. maximising economic efficiency). Any new gear modification aimed at reducing bycatch may meet opposition from fishery operators if the new requirements are perceived to, or actually reduce commercial catches or increase fuel consumption, thus reducing profits. Casale et al. (2004) considered TEDs as an unrealistic solution for reducing turtle bycatch in Mediterranean mixed bottom trawl fisheries, due to the high risk of commercial losses. In this study, the flexible TED tested in coastal trawling, affected neither technical performances nor catching efficiency. Horizontal and vertical net opening, door spread, and the force required to tow the two nets were not significantly different. The TED therefore did not affect trawl behaviour nor fuel consumption, which is strongly related to towing force (Prat et al. 2008; Sala et al. 2011). Regarding catching efficiency, the commercial catch fractions showed no major differences between the two nets, whereas debris and marine litter were reduced in hauls performed with the TED. The removal of debris from the cod-end catch is beneficial both because it (a) increases available space in the net for commercial species, and (b) improves the quality of catch by the removal of large objects that might otherwise damage the catch. Therefore, debris reduction might encourage fishermen to adopt the device voluntarily.

The selective performance of the net was unchanged with the addition of the TED. In fact, there was no appreciable difference in the size frequency distributions of the fish caught. M. merluccius and S. solea specimens below the MCRS were commonly found in both trawls. This finding is however largely related to the multispecies nature of Mediterranean fisheries and to the suboptimal selectivity of demersal trawls (Lucchetti 2008; Sala and Lucchetti 2010, 2011; Sala et al. 2008; 2015).

The present study demonstrates that a flexible TED can be considered an effective and practical tool to reduce turtle bycatch in Mediterranean coastal trawl fisheries without compromising commercial catches. Nevertheless, the implementation of management measures must take into account the response of fishers (Bellido et al. 2011; Santiago et al. 2015). For this purpose, dissemination of results among fishermen should now follow, although more tests in deeper areas should also be conducted.

Even though the number of turtles caught with the traditional net (one) and released with TED (two) was very low and statistically not significant, the results are promising, because the exclusion of considerable amounts of marine litter strongly suggests that the flexible TED can be equally effective with turtles, which moreover can actively swim out of the net.

In a future perspective, fishermen can be incentivised to adopt TED on a voluntary basis, by giving added market value to the fish caught with these "environmentally friendly" devices, through quality certification of fish products.

According to Casale et al. (2015), one of the major shortcomings in Mediterranean sea turtle conservation is lack of knowledge on population dynamics and survival probabilities. The bottom trawl fisheries in the Adriatic Sea mainly impact juveniles and sub-adults, which represent the bulk of the population and whose survival has the greatest effect on population growth. A pilot study in the Adriatic Sea based on a risk-analysis approach identified areas and seasons of possible trawling-turtle interactions (Lucchetti et al. 2016). The results revealed that turtles which were monitored by satellite tracking spent the whole year in the Adriatic and major bycatch hotspots were identified in the northernmost western part in spring and south of the River Po delta in autumn, especially at depths shallower than $40 \mathrm{~m}$. In these areas, the TED tested in the present study was highly efficient. Therefore, adoption of the TED in critical areas and seasons, together with other management measures, has the potential to provide a substantial contribution to the conservation of $C$. caretta in the whole Mediterranean Sea. Furthermore, studies of population dynamics and identification of bycatch hot-spots, coupled with bycatch reduction devices (BRDs), spatio-temporal closure of some areas and awareness campaigns, may contribute to more effective management of fisheries and to the conservation of endangered species at a global scale. Therefore, effective and strict cooperation between scientists, fishing operators and management bodies is of paramount importance, as established in the EAF (Ecosystem Approach to Fisheries) guidelines (Garcia and Cochrane 2005).

Acknowledgements. This research study was authorised by the Italian Coast Guard. It was conducted with the contribution of the LIFE financial instrument of the European Community, project TartaLife Reduction of sea turtle mortality in professional fishing (LIFE12 NAT/IT/000937). It does not necessarily reflect the European Commission's views and in no way anticipates future policy. This support is gratefully acknowledged. We are indebted to CNR-ISMAR, Ancona personnel, and to the crew of R/V G. Dallaporta for their huge effort in the fieldwork. We would also like to thank Word Designs (Italy) for the language revision (www.silviamodena.com).

\section{References}

Adriatic Sea Turtles Database, 2015, European project IPA Adriatic "NETCET, a network for the conservation of cetaceans and sea turtles in the Adriatic Sea"(2012-2015). Available at: http://www. adriaticseaturtles.eu/.

Anderson M.J., 2001, A new method for non-parametric multivariate analysis of variance. Aust. J. Ecology 26, 32-46.

Arendt M.D., Schwenter J.A., Witherington B.E., Meylan A.B., Saba V.S., 2013, Historical versus contemporary climate forcing on the annual nesting variability of loggerhead sea turtles in the Northwest Atlantic Ocean. PLoS ONE 8: e81097.

Bahamon N., Sardà F., Suuronen P., 2007, Selectivity of flexible sizesorting grid in Mediterranean multispecies trawl fishery. Fish. Sci. 73, 1231-1240.

Bellido J.M., Begoña Santos M., Pennino M.G., Valeiras X., Pierce G.J., 2011, Fishery discards and bycatch: solutions for an ecosystem approach to fisheries management? Hydrobiologia 670, 317 333.

Bianchi C.N., Morri C., 2000, Marine Biodiversity of the Mediterranean Sea: Situation, Problems and Prospects for Future Research. Mar. Pollut. Bull. 40, 367-376.

Camiñas J.A., 2004, Sea turtles of the Mediterranean Sea: population dynamics, sources of mortality and relative importance of fisheries impacts. FAO Fish. Rep. 738, 27-84. 
Casale P., 2011, Sea turtle by-catch in the Mediterranean. Fish. Fish. $12,299-316$.

Casale P., Affronte M., Scaravelli D., Lazar B., Vallini C., Luschi P., 2012, Foraging grounds, movement patterns and habitat connectivity of juvenile loggerhead turtles $(C$. caretta) tracked from the Adriatic Sea. Mar. Biol. 159, 1527-1535.

Casale P., Freggi D., Furii G., Vallini C., Salvemini P., Deflorio M., Totaro G., Raimondi S., Fortuna C., Godley B., 2015, Annual survival probabilities of juvenile loggerhead sea turtles indicate high anthropogenic impact to Mediterranean populations. Aquatic Conserv: Mar. Freshw. Ecosyst. 25, 690-700.

Casale P., Laurent L., De Metrio G., 2004, Incidental capture of marine turtles by the Italian trawl fishery in the north Adriatic Sea. Biol. Cons. 119, 287-295.

Casale P., Tucker A.D., 2015, Caretta caretta. The IUCN Red List of Threatened Species 2015: e.T3897A83157651. http://dx.doi.org/ 10.2305/IUCN.UK.2015-4.RLTS.T3897A83157651.en.

Charbonnier D., 1990, Pêche et Aquaculture en Méditerranée. Etat et Perspectives. Programme des Nations Unies pour l'Environnement. Plan d'Action pour la Méditerranée. Les Fascicules du Plan bleu. Edts Economica, Paris; 94 p.

Clarke, KR., 1993, Non-parametric multivariate analyses of changes in community structure. Aust. J. Ecol. 18, 117-143.

Cochran W.G., 1977, Sampling techniques. Wiley, New York.

Coll M., Libralato S., 2012, Contributions of food web modelling to the ecosystem approach to marine resource management in the Mediterranean Sea. Fish Fish. 13, 60-88.

Coll M., Piroddi C., Kaschner K., et al., 2010, The biodiversity of the Mediterranean Sea: estimates, patterns and threats. PLoS ONE 5, doi : 10.1371.

Council Regulation (EC) No 1967/2006 of 21 December 2006, concerning management measures for the sustainable exploitation of fishery resources in the Mediterranean Sea, amending Regulation (EEC) No 2847/93 and repealing Regulation (EC) No 1626/94. Official Journal of the European Union L. 409.

Crouse D.T., Crowder L.B., Caswell H., 1987, A stage-based population model for loggerhead sea turtles and implications for conservation. Ecology 68, 1412-1423.

Crowder L.B., Crouse D.T., Heppell S.S., Martin T.H., 1994, Predicting the impact of turtle excluder devices on loggerhead sea turtle populations. Ecological Applications 4, 437-445.

Eayrs S., 2007, A Guide to Bycatch Reduction in Tropical ShrimpTrawl Fisheries. Revised edition. Rome, FAO, 108 p.

Eleftheriou A., Anagnostopoulou-Visilia E., Anastasopoulou E., Ateş S.A., Bachari N., El I., et al., 2011, New Mediterranean biodiversity records (December 2011). Medit. Mar. Sci. 12, 491-508.

Epperly S.P., 2003, Fisheries-related mortality and Turtle Excluder Devices (TEDs). In: Lutz P.L., Musick J.A. (Eds.), The Biology of Sea Turtles. CRC Marine Science Series, CRC Press, Inc., Boca Raton, Florida, pp. 339-353.

Farrugio H., Oliver P., Biagi F., 1993, An overview of the history, knowledge, recent and future research trends in Mediterranean fisheries. Sci. Mar. 57, 105-119.

Fortuna C.M., Vallini C., Filidei Jr. E., Ruffino M., Consalvo I., Di Muccio S., Gion C., Scacco U., Tarulli E., Giovanardi O., Mazzola A., 2010, By-catch of cetaceans and other species of conservation concern during pair trawl fishing operations in the Adriatic Sea (Italy). Chem. Ecol. 26, 65-76.

Garcia S.M., Cochrane K.L., 2005, Ecosystem approach to fisheries: a review of implementation guidelines. ICES J. Mar. Sci. 62, 311318.

Gullett W., 2003, Enforcing bycatch reduction in trawl fisheries: legislating for the use of turtle exclusion devices. Environ. Planning Law J. 20, 195-210.
Halpern B.S., Walbridge S., Selkoe A.K., Kappel C.V., Micheli F., et al. 2008, A global map of human impact on marine ecosystems. Science 319, 948-952.

He P., Balzano V., 2012, The effect of grid spacing on size selectivity of shrimps in a pink shrimp trawl with a dual-grid size-sorting system. Fish. Res. 121-122, 81-87.

Henwood T.A., Stuntz W.E., 1987, Analysis of sea turtle captures and mortality during commercial shrimp trawling. Fish. Bull. US 85, 813-817.

Jenkins L.D., 2012, Reducing Sea Turtle Bycatch in Trawl Nets: A History of NMFS Turtle Excluder Device (TED) Research. Mar. Fish. Rev. 74, 26-44.

Laurent L., Abd El-Mawla E.M., Bradai M.N., Demirayak F., Oruc A., 1996, Reducing sea turtle mortality induced by Mediterranean fisheries: trawling activity in Egypt, Tunisia and Turkey. Report for the WWF International Mediterranean Programme. WWF Project 9E0103, 32 p.

Laurent L., Lescure J., 1994, L'hivernage des tortues caouannes Caretta caretta (L.) dans le sud Tunisien. Revue d'Ecolgie-La Terre et la Vie 49, 63-86.

Lazar B., Tvrtkovic N., 1995, Marine turtles in the eastern part of the Adriatic Sea: preliminary research. Natura Croatica 4, 59-74.

Lindman H.R., 1992, Analysis of variance in experimental design. Springer texts in statistics. Springer-Verlag Publishing, New York, USA. 531 p.

Lleonart J., Maynou F., 2003, Fish stock assessments in the Mediterranean: state of the art. Sci. Mar. 67, 37-49.

Lucchetti A., 2008, Comparison of diamond- and square-mesh codends in the hake (Merluccius merluccius L. 1758) trawl fishery of the Adriatic Sea (central Mediterranean). Sci. Mar. 72, 451460.

Lucchetti A., Piccinetti C., Meconi U., Frittelloni C., Marchesan M., Palladino S., Virgili M., 2014, Transferable Fishing Concessions (TFC): A pilot study on the applicability in the Mediterranean Sea. Marine Policy 44, 438-447.

Lucchetti A., Pulcinella J., Agelini V., Pari S., Russo T., Cataudella S., 2016, An interaction index to predict turtle bycatch in a Mediterranean bottom trawl fishery. Ecological Indicators 60, 557-564.

Lucchetti A., Sala A., 2010, An overview of loggerhead sea turtle (Caretta caretta) bycatch and technical mitigation measures in the Mediterranean Sea. Rev. Fish Biol. Fish. 20, 141-161.

Lutcavage M.E., Lutz P.L., 1997, Diving physiology. In: Lutz P.L., Musick J.A. (Eds.). The Biology of Sea Turtles. CRC Marine Science Series, CRC Press, Inc., Boca Raton, Florida, pp. 277 296.

Mazaris A.D., Matsinos Y.G., 2006a, An individual based model of sea turtles: Investigating the effect of temporal variability on population dynamics. Ecol. Modell. 194, 114-124.

Mazaris A.D., Broder B., Matsinos Y.G., 2006b, An individual based model of a sea turtle population to analyze effects of age dependent mortality. Ecol. Modell. 198, 174-182.

Mazaris A.D., Fiksen O., Matsinos Y.G., 2005, Using an individualbased model for assessment of sea turtle population viability. Population Ecology 47, 179-191.

McArdle B.H., Anderson M.J., 2001, Fitting multivariate models to community data: a comment on distance-based redundancy analysis. Ecology 82, 290-297.

Mitchell J.F., Watson J.W., Foster D.G., Caylor R.E., 1995, The Turtle Excluder Device (TED): A guide to better performance. NOAA Technical Memorandum NMFS-SEFSC.

Myers N., Mittermeier R.A., Mittermeier C.G., da Fonseca G.A.B, Kent J., 2000, Biodiversity hotspots for conservation priorities. Nature 403, 853-858. 
Papaconstantinou C., Farrugio H., 2000, Fisheries in the Mediterranean. Medit. Mar. Sci. 1, 5-18.

Prat Farran J., Antonijuan J., Folch A., Sala A., Lucchetti A., Sardà F., Manuel A., 2008, A simplified model of the interaction of the trawl warps, the otterboards and netting drag. Fish. Res. 94, 109_ 117.

Robins J.B., Campbell M.J., Mc Gilvray J.G., 1999, Reducing Prawntrawl Bycatch in Australia: An Overview and an Example from Queensland. Mar. Fish. Rev. 61, 46-55.

Sala A., Lucchetti A., 2010, The effect of mesh configuration and codend circumference on selectivity in the Mediterranean trawl Nephrops fishery. Fish. Res. 103, 63-72.

Sala A., Lucchetti A., 2011, Effect of mesh size and codend circumference on selectivity in the Mediterranean demersal trawl fisheries. Fish. Res. 110, 252-258.

Sala A., Lucchetti A., Affronte M., 2011, Effects of Turtle Excluder Devices (TEDs) on bycatch and discards reduction in the demersal fisheries of Mediterranean Sea. Aquat. Living Resour. 24, 183-192.

Sala A., Lucchetti A., Perdichizzi A., Herrmann B., Rinelli P., 2015, Is square-mesh better selective than larger mesh? A perspective on the management for Mediterranean trawl fisheries. Fish. Res. 161, 182-190.

Sala A., Lucchetti A., Piccinetti C., Ferretti M., 2008, Size selection by diamond- and square-mesh codends in multi-species Mediterranean demersal trawl fisheries. Fish. Res. 93, 8-21.

Santiago J.L., Ballesteros M., Chapela R., Silva C., Nielsen K.N., Rangel M., Erzini K., Wise L., Campos A., Borges M.F., Sala A., Virgili M., Viðarsson J.R., Baudron A., Fernandes P.G., 2015, Is Europe ready for a results-based approach to fisheries management? The voice of stakeholders. Marine Policy 56, 86-97.
Sardà F., Bahamon N., Molí B., Sardà-Palomera F., 2006, The use of a square mesh and sorting grids to reduce catches of young fish and improve sustainability in a multispecies bottom trawl fishery in the NW Mediterranean Sea. Sci. Mar. 70, 347-353.

Sasso C.R., Epperly S.P., 2006, Seasonal sea turtle mortality risk from forced submergence in bottom trawls. Fish. Res. 81, 86-88.

Sokal R.R., Rohlf F.J., 1995, Biometry. The principle and practice of statistics in biological research. San Francisco, WH Freeman.

Scientific, Technical and Economic Committee for Fisheries (STECF), 2015. The 2015 Annual Economic Report on the EU Fishing Fleet (STECF 15-07). Paulrud, Carvalho, Borrello, Motova (Eds.) 434 pp.

Tittensor D.P., Mora C., Jetz W., Lotze H.K., Ricard D., Berghe E.V., et al., 2010, Global patterns and predictors of marine biodiversity across taxa. Nature 466, 1098-1101.

Tomas J., Aznar F.J., Raga J.A., 2001, Feeding ecology of the loggerhead turtle Caretta caretta in the western Mediterranean. J. Zool. $255,525-532$.

Tudela S., 2004, Ecosystem effects of fishing in the Mediterranean: an analysis of the major threats of fishing gear and practices to biodiversity and marine habitats. Studies and Reviews. General Fisheries Commission for the Mediterranean. No. 74. Rome, FAO. p. 44.

Wallace B.P., DiMatteo A.D., Bolten A.B., Chaloupka M.Y., Hutchinson B.J., Abreu-Grobois F.A., et al. 2011, Global conservation priorities for marine turtles. PLoS One 6, e24510, doi: 10.1371/journal. pone.0024510.

Worm B., Barbier E.B., Beaumont N., Duffy J.E., Folke C., Halpern B.S., et al., 2006, Impacts of biodiversity loss on ocean ecosystem services. Science 314, 787-790. 